\title{
Changes in rangeland pricing method during the inflation-deflation price cycle
}

\author{
R.C. ROWAN AND JOHN P. WORKMAN
}

\begin{abstract}
Authors are graduate research assistant, Department of Rangeland Ecology and Management, Texas A\&M University, College Station 77843-2126; and professor, Department of Range Science, Utah State University, Logan 84322-5230. At the time of the research, Rowan was graduate research assistant at Utah State University.
\end{abstract}

\section{Abstract}

Utah rangeland real estate underwent an inflation-deflation price cycle from 1975 through 1988 . A total of 166 Utah land sales were analyzed to determine whether factors affecting rangeland prices changed during the price cycle. Regression analysis was used to test changes in method of pricing rangeland between the inflation phase (1975-81) and deflation phase (1982-87). The effects on sale price of parcel size (acres or hectares) and number of deeded animal unit months (AUMs) differed between the 2 time periods. Size of parcel sold significantly affected land price in the first time period, but not in the second. Conversely, the number of deeded AUMs did not significantly influence land price in the first time period, but did in the second. Thus rangeland tended to be priced per acre (hectare) during the inflation phase of the price cycle and per AUM of carrying capacity during the deflation phase. These results indicate that rangeland owners should try to maintain or improve range condition and carrying capacity to preserve real estate values during deflationary times.

Key Words: range appraisal, price per animal unit, price per acre, carrying capacity value

Cropland is commonly priced on a unit price basis (dollars per acre or hectare). Potential buyers make subjective judgments about the quality of the cropland. This is normally done for each soil type in order to arrive at a total land value based on production potential. Rangeland has traditionally been priced in a similar manner with value expressed in terms of sustainable grazing capacity (typically as dollars per animal unit month). However, the rural real estate markets of the 1970's brought some changes in pricing practices.

Agricultural land prices peaked in the early 1980's and then fell dramatically (USDA 1988). During the inflation phase of the price cycle, one often heard the statement that a farm had "sold for more than it was worth"(Suter 1980). This statement refers to 2 different concepts of value: value-in-exchange and earnings value. Value-inexchange is the concept upon which the market transfer of land is based. However, if revenue from inflated land cannot cover loan payments, earnings value is less than value-in-exchange (Fig. 1). Suter (1980) identified "basic farm value" as the valuation technique that capitalizes long term earnings potential into land value. This technique was rarely used during the inflation phase of the price cycle because it did not accurately estimate agricultural land prices.

Factors other than earnings may partially account for inflated farm and ranch prices. Figure 2 compares Utah real estate values (USDA 1984, 1988) and a proxy index for net ranch income, which

Supported by the Utah Agricultural Experiment Station, Utah State University, Logan 84322-4845. Approved as journal paper 4247.

Manuscript accepted 18 Mar. 1992 is the difference between the Beef Cattle Price Index and the Prices Paid Index (USDA 1987). Although earnings declined throughout the 1975-87 period, land values increased until 1982.

Each of the 3 standard appraisal techniques (cost approach, market data approach, and income approach) attempts to estimate real estate value in terms of current market price (Suter 1980). As noted above, the income capitalization approach often has not been a reliable estimator of farm and ranch values during the inflation phase of the price cycle. Only when appraisers have used a market-derived real capitalization rate (rather than a real borrowing or real opportunity cost rate) has the income approach been accurate. The correlation between earnings potential and sale price is critical for many buyers, especially if farm and ranch income is the only source of revenue. However, Godfrey and Andersen (1988) noted that over $95 \%$ of Utah farmers had some source of nonfarm income.

We hypothesized that prior to 1975 (the approximate beginning of the most recent inflation cycle) Utah ranch real estate was priced not in terms of dollars per acre (hectare), but on a dollars per animal unit month (AUM) basis. We further hypothesized that during the years of rapid land appreciation, Utah rangeland sold on a dollars per acre (hectare) basis. Nonfarm opportunities such as residential development, recreation potential, and mineral reserves may have influenced land values. Thus purchasers may have ignored differences in land productivity and based purchasing decisions solely on number of acres (hectares) rather than on livestock carrying capacity. Finally, we hypothesized that since the 1982 price decline (a decline in both per acre and per AUM prices), rangeland has once again sold by the AUM. If true, it would be extremely important for land owners to maintain (or improve) range condition and carrying capacity in order to preserve land values during the deflation phase of the land price cycle.

\section{Methods}

Rangeland prices during $1975-81$ and $1982-87$ were analyzed by regression equations for each of the 2 periods to test for any differences in pricing methods between the 2 periods. The relevant question was: on what basis has rangeland been priced in the market during the period 1975-87?

Comparing 166 individual Utah ranch sales over the period 1975-87 involved analysis of data collected by King (1981) along with those of this study. Combining data required that variables for the 2 studies be defined and measured in the same manner. For example, King's measure for carrying capacity was in brood cow units. These were converted to AUMs by multiplying brood cow units by 1.2 animal units yearlong/brood cow unit and then by 12 months (Workman and King 1982).

The peak land price month was identified as February 1982 (USDA 1984 and 1988) and the combined data were divided into 2 


\section{Repayment ability Vs. Percent financed Mountain States}



Repayment Index $1 /$ Percent financed $2 /$

1/ Gertel, personal communication

2/ Farm Real Estate Market Developments

2/ Agricultural Resources

Fig. 1. Repayment ability index (in percent) compared to the average percent financed on farm and ranch land in the mountain states for 1975-88.

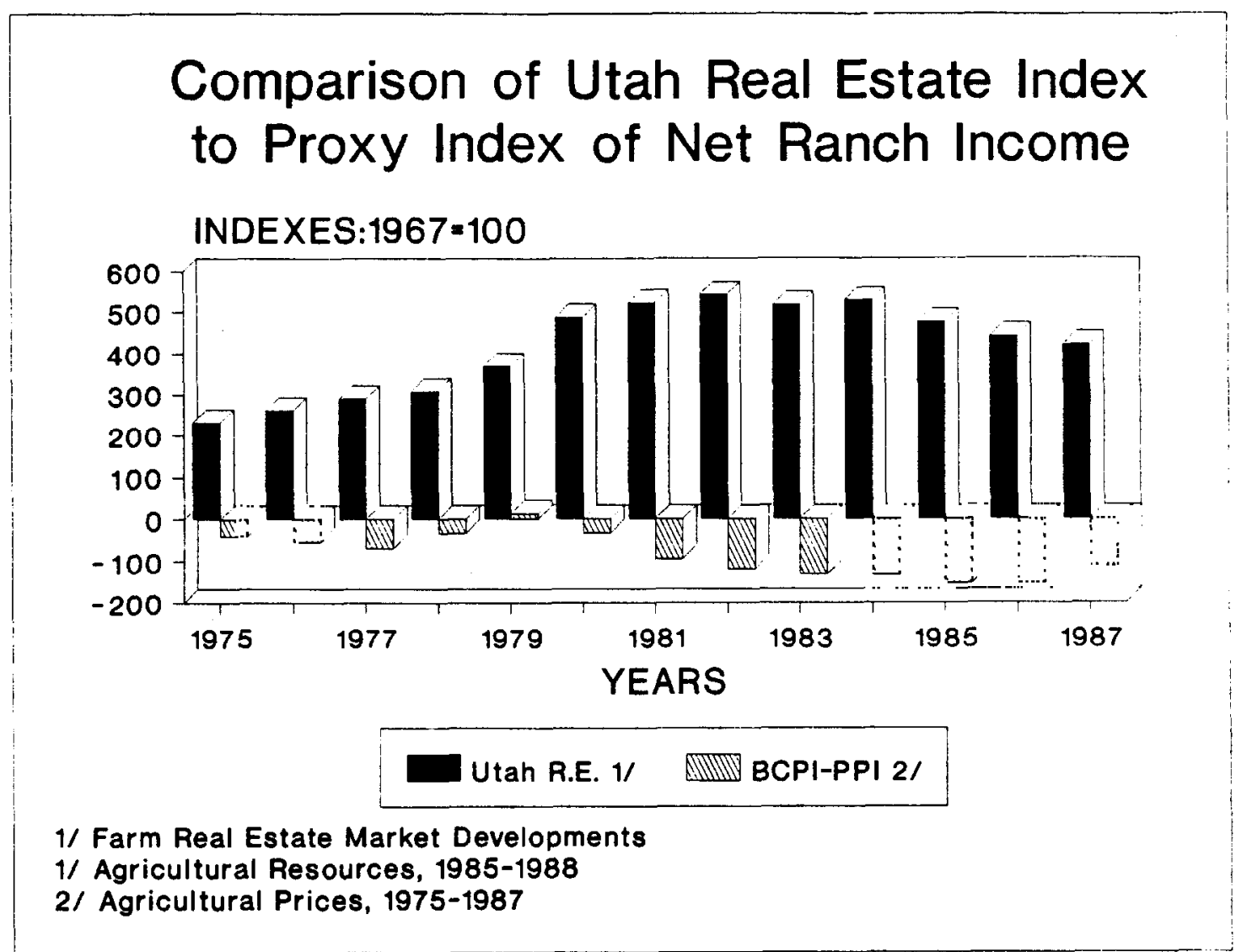

Fig. 2. A comparison of the Utah real estate index (Utah R.E.) to a proxy index for net ranch income for 1975-87. The proxy index (BCPI-PPI) is the difference between the Beef Cattle Price Index (BCPI) and the Prices Paid Index (PPI). 


\section{Percent Change in CPI Index Compared to Change in Utah R.E. Index}

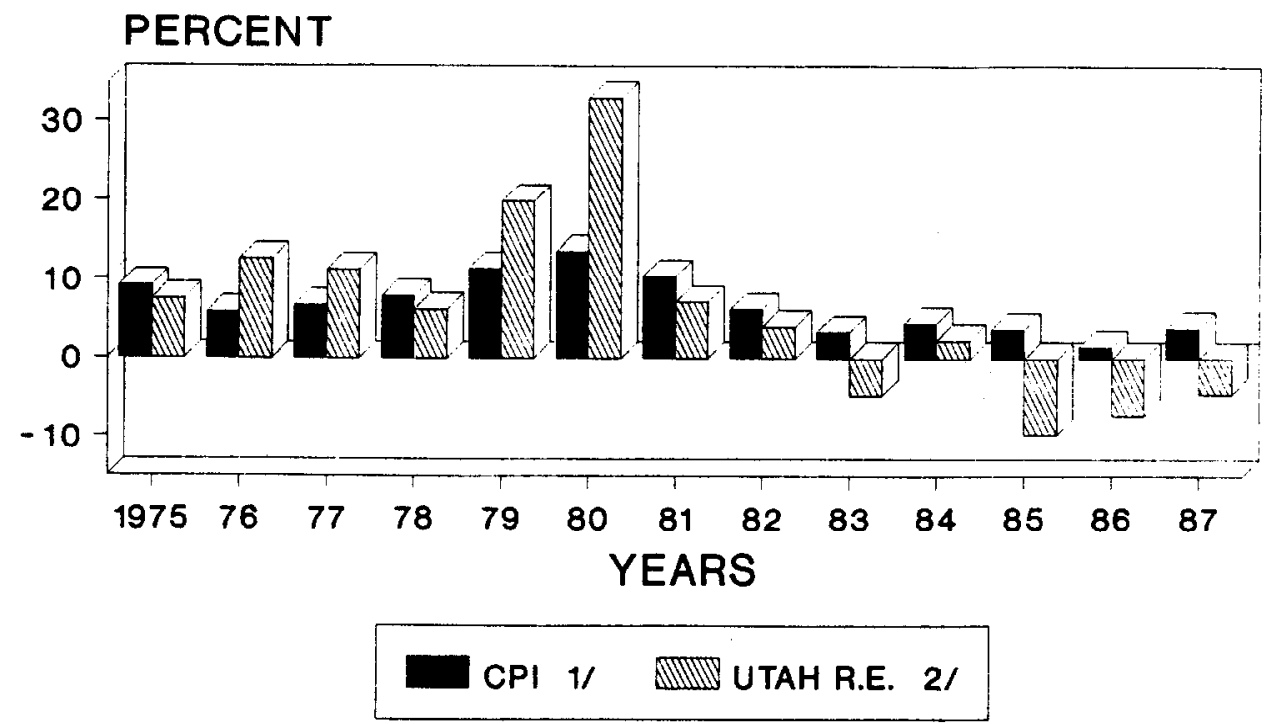

1/ Statistical Abstract of the U.S.

2/ Farm Real Estate Market Developments

2/ Agricultural Resources, 1985-1988

Fig. 3. Percent change in the Consumer Price Index (CPI) compared to the change in the Utah Real Estate Index (Utah R.E.) for 1975-87.

time periods based on that month. Figure 3 shows the rise and fall of land values in Utah over the price cycle. The annual percentage change in dollars per acre (hectare) increased rapidly during 1979 and 1980. With the exception of 1984, annual changes during the period 1982 to 1987 were negative.

The regression model estimated total ranch sale price as a function of size of sale (Acres), deeded carrying capacity (Daums), leased carrying capacity (Laums), value of dwellings and buildings (Dwell), distance to town (Dist), index variables for sale size $\left(\mathbf{S}_{1}\right.$ and $S_{2}$ ), and an index variable for the stage of the land price cycle (P). The dependent variable was expressed as total ranch sale price in nominal dollars, following the methods of Torell and Fowler (1986). Carrying capacity variables (deeded and leased) were measured in animal unit months. Total value of dwellings and buildings included in land sales was expressed in dollars.

Distance values were measured as the shortest distance in miles along established roads from the ranch to a Utah town of at least 2,000 people (Andriot 1983). Measurements were made to the nearest mile using the Sigma Scan digitizing program (Jandel Scientific, Corte Mandera, Calif.)

The index (dummy) variables for size of sale $(<40,40-640$, and $>640$ acres) followed the methods of Rowan and Workman (1992) and were represented as:

$$
\begin{aligned}
\mathrm{S}_{1} & =1 \text { if size is }<40 \text { acres } \\
& =0 \text { if size is } 40-640 \text { acres } \\
& =-1 \text { if size is }>640 \text { acres } \\
\mathrm{S}_{2} & =0 \text { if size is }<40 \text { acres } \\
& =1 \text { if size is } 40-640 \text { acres } \\
& =-1 \text { if size is }>640 \text { acres. }
\end{aligned}
$$

Stage of the land price cycle was represented by a dummy variable (Gujarati 1988) for the 2 time periods (P). The period
January 1975 to February 1982 was assigned a value of $P=0$ and the period March 1982 to December 1987 a value of $P=1$. Each independent variable value was multiplied by the binary value for its respective time period. The regression model was defined as:

$$
\begin{aligned}
& \hat{Y}_{i}=\alpha_{0}+\alpha_{1} P_{i}+\beta_{1} X_{1}+\beta_{2}\left(P_{i} X_{1}\right)+\beta_{3} X_{2} \\
& +\beta_{4}\left(P_{i} X_{2}\right)+\ldots . \beta_{2 k-1} X_{k}+\beta_{2 k}\left(P_{i} X_{k}\right)+\epsilon_{i}
\end{aligned}
$$

where

$\hat{Y}_{i}=$ total ranch sale price,

$P_{i}=1$ if sale occurred after February, 1982,

$P_{i}=0$ if sale occurred February, 1982, or earlier,

$X_{i}=1,2 \ldots . . k=$ independent variables:

Acres $=$ size of sale

Daums $=$ deeded carrying capacity

Laums = leased carrying capacity

Dwell = value of dwellings and buildings $(\$)$

Dist = distance to a town of 2,000 population (miles),

$S_{1}$ and $S_{2}=$ index variables for ranch sale size, and

$\epsilon_{i}=$ error term.

This model identified $\alpha_{1}$ as the differential intercept coefficient. If significant at a t-test probability $<0.05$, this coefficient indicates that the second time period $\mathrm{Y}$-axis intercept differs significantly from that of the first time period. In the same manner, $\beta_{2}$, $\beta_{4}, \ldots \beta_{2 k}$ are the differential slope coefficients which indicate whether or not the independent variable slope coefficients of the first time period differ from those of the second time period.

Regressions for both time periods were estimated from this 1 regression model (Gujarati 1988). They were:

First time period (1975-81)

$$
\hat{\mathbf{Y}}_{\mathrm{i}}=\alpha_{0}+\beta_{1} \mathrm{X}_{1}+\ldots \beta_{\mathbf{k}} \mathbf{X}_{\mathbf{k}}+\epsilon_{\mathrm{i}}
$$


where $\mathrm{i}=1,2 \ldots \mathrm{k}$, and

\section{Second time period (1982-87)}

$$
Y_{i}=\left(\alpha_{0}+\alpha_{1}\right)+\left(\beta_{1}+\beta_{2}\right) X_{1}+\ldots\left(\beta_{2 k-1}+\beta_{2 k}\right) X_{k}+\epsilon_{j} .
$$

The combined coefficients of $\left(\beta_{1}+\beta_{2}\right) \ldots\left(\beta_{2 k-1}+\beta_{2 k}\right)$ were tested for significance using the formula:

$$
t=\frac{\left(\beta_{1}+\beta_{2}\right)}{S_{E}\left(\beta_{1}+\beta_{2}\right)}
$$

where

$S_{E}\left(\beta_{1}+\beta_{2}\right)=\sqrt{V\left(\beta_{1}\right)+V\left(\beta_{2}\right)+2 \operatorname{Cov}\left(\beta_{1} \beta_{2}\right)}$

This $t$-value was derived differently than those for the other regression coefficients since it considered the sum of individual variances of $\beta_{1}$ and $\beta_{2}$ plus the covariance of these coefficients.

One additional test was used to determine whether ranches were priced differently before and after the peak price year: restricted and unrestricted regression models. Land sales were divided into the same 2 time periods described above. Next a "restricted" regression was estimated for the first time period (1975-81) based on the following independent variables: Acres, Dwell, Dist, and ranch size index variables $\left(S_{1}\right.$ and $\left.S_{2}\right)$. Then an "unrestricted" regression was estimated for $1975-81$ based on the same set of independent variables plus Daums and Laums. An F-test was then applied to test whether deeded and leased carrying capacity significantly affected total ranch sale price during the first time period (1975-81).

Similar "restricted" and "unrestricted" regressions were estimated to determine if size of sale (Acres) significantly affected total sale price during the second time period (1982-87). The restricted regression included the following variables: Dwell, Dist, ranch size index variables $\left(S_{1}\right.$ and $\left.S_{2}\right)$, Daums, and Laums. The unrestricted regression included the same set of independent variables plus size of sale (Acres).

The formula for the F-ratio was:

$$
F=\frac{\left(R^{2}{ }_{U R}-R^{2} R\right) / m}{\left(1-R^{2} U R\right) /(N-k)}
$$

where

$$
\begin{array}{ll}
\mathbf{R}^{2} \mathrm{UR} & =\mathbf{R}^{2} \text { value obtained from unrestricted regression } \\
\mathbf{R}^{2} \mathbf{R} & =\mathbf{R}^{2} \text { value obtained from restricted regression } \\
\mathbf{m} & =\text { number of linear restrictions } \\
\mathbf{k} & =\text { number of parameters in unrestricted regression } \\
\mathbf{N} & =\text { number of observations }
\end{array}
$$

\section{Results and Discussion}

Prices of Utah ranches sold before and after the peak year (1982) were compared to identify changes in the method of pricing rural real estate from 1975 through 1987. Applying Gujarati's (1988) dummy variable regression approach to the analysis of differences in land pricing method between the 2 phases of the land price cycle yielded a significant ANOVA difference $(P<0.0001)$ between the 2 phases in the coefficients for Acres and Daums. The 2 time-period equations were derived from the same regression model. If differential slope coefficients were statistically significant $(P<0.05)$, they were added to independent variable coefficients for the first time period, resulting in the equation for the second time period (Table 1). The combined coefficients were then re-tested using the t-test formulation described above. The 2 time period regressions were:

First time period 1975-81: Total ranch price $=$

\begin{tabular}{|c|c|c|c|}
\hline Variables & $\begin{array}{l}\text { First time } \\
\text { period }\end{array}$ & $\begin{array}{l}\text { Differential } \\
\text { terms }\end{array}$ & $\begin{array}{l}\text { Second time } \\
\text { period }\end{array}$ \\
\hline Intercept & $\begin{array}{c}+354,037.27 * * \\
(80,929.26)\end{array}$ & $\begin{array}{r}-140,077.53 \\
(98,400.20)\end{array}$ & $\begin{array}{c}+354,037.27 * * \\
(80,929.26)\end{array}$ \\
\hline $\begin{array}{l}\text { Number } \\
\text { Acres }\end{array}$ & $\begin{array}{l}102.75^{* *} \\
(15.70)\end{array}$ & $\begin{array}{c}-103.06^{* *} \\
(20.87)\end{array}$ & $\begin{array}{c}-0.31 \\
(13.50)\end{array}$ \\
\hline $\begin{array}{l}\text { Number } \\
\text { Daums }\end{array}$ & $\begin{array}{c}+4.06 \\
(33.19)\end{array}$ & $\begin{array}{c}+93.57^{*} \\
(46.45)\end{array}$ & $\begin{array}{l}+97.63^{* *} \\
(32.49)\end{array}$ \\
\hline $\begin{array}{l}\text { Number } \\
\text { Laums }\end{array}$ & $\begin{array}{c}+14.84 \\
(22.22)\end{array}$ & $\begin{array}{l}+11.92 \\
(39.58)\end{array}$ & $\begin{array}{l}+14.84 * * \\
(22.22)\end{array}$ \\
\hline $\begin{array}{l}\text { Dollars o } \\
\text { Dwellings }\end{array}$ & $\begin{array}{l}+2.50^{* *} \\
(0.72)\end{array}$ & $\begin{array}{c}+1.73 \\
(1.41)\end{array}$ & $\begin{array}{l}+2.50^{* *} \\
(0.72)\end{array}$ \\
\hline $\begin{array}{c}\text { Miles of } \\
\text { Distance } \\
\text { Dummy }\end{array}$ & $\begin{array}{c}-2,832.25 \\
(1,626.52)\end{array}$ & $\begin{array}{c}-715.30 \\
(2,060.64)\end{array}$ & $\begin{array}{c}-2,832.25 \\
(1,626.52)\end{array}$ \\
\hline $\begin{array}{l}S_{1} \\
\text { Dummy }\end{array}$ & $\begin{array}{c}+58,809.11 \\
(98,600.63)\end{array}$ & $\begin{array}{c}-164,388.51 \\
(118,005.69)\end{array}$ & $\begin{array}{c}+58,809.11 \\
(98,600.63)\end{array}$ \\
\hline$*=s i$ & $\begin{array}{c}-101,306.57 \\
(69,640.61) \\
\text { level } 0.05\end{array}$ & $\begin{array}{l}+61,207.51 \\
(85,483.90) \\
\text { significance level }\end{array}$ & $\begin{array}{l}-101,306.57 \\
(69,640.61) \\
0.01^{-1}\end{array}$ \\
\hline
\end{tabular}

$354,037.27^{* *}+102.75^{* *}$ (Acres) +4.06 (Daums) +

$(80,929.26) \quad(15.70) \quad(33.19)$

14.84 (Laums) $+2.50^{* *}($ Dwell $)-2,832.25$ (Dist) +

(22.22) (0.72) $(1,626.52)$
Table 1. Variables showing significance at the 0.05 and 0.01 levels in the 2 time period regression, 1975-81 and 1982-87.

$58,809.11\left(\mathrm{~S}_{1}\right)-101,306.57\left(\mathrm{~S}_{2}\right)$

$(98,600.63) \quad(69,640.61)$

* = significance level $0.05 * *$ = significance level 0.01

Numbers in parentheses below coefficients are standard errors of the coefficients.

Second time period 1982-87: Total ranch price $=$

$354,037.27 * *-0.31$ (Acres) + 97.63(Daums) +

$(80,929.26) \quad(13.50) \quad(32.49)$

14.84 (Laums) $+2.50 * *($ Dwell $)-2,832.25($ Dist $)+$

$(22.22) \quad(0.72) \quad(1,626.52)$

$58,809.11\left(\mathrm{~S}_{1}\right)-101,306.57\left(\mathrm{~S}_{2}\right)$

$(98,600.63) \quad(69,640.61)$

$*$ = significance level $0.05 * *$ = significance level 0.01

These regressions indicate that number of acres sold was a significant predictor of total ranch sale price during 1975-81, but was no longer significant after 1981. Conversely, deeded carrying capacity was a significant predictor after 1981 , but not before.

The final test of differences in the contribution of number of acres, number of deeded AUMs, and number of leased AUMs between the 2 time periods was conducted with restricted and unrestricted regressions. The first time period comparison(1975-81), which added Daums and Laums to a restricted model already containing number of acres, dwelling value, distance, and sale size index variables $S_{1}$ and $S_{2}$, gave an insignificant $F$-value. It was concluded that (1) carrying capacity did not significantly affect total ranch sale price during the period 1975-81 and (2) during this period land was priced by the acre (hectare) rather than by the AUM of carrying capacity. Likewise, the second time period comparison (1982-87), which added acres to a restricted model already containing Daums, Laums, Dwell, Dist, $S_{1}$, and $S_{2}$, also gave an insignificant $F$-value. Thus, number of acres (hectares) did not significantly affect total ranch price during 1982-87 and during this period land was priced by the AUM rather than by the acre (hectare).

Scott (1983) reported that farmers and ranchers have traditionally purchased land if it requires revenue from no more than 2 acres (hectares) to make payments on 1 additional acre (hectare). How- 
ever, this rule of thumb may be optimistic for Utah operators. Godfrey and Andersen (1988) noted that Utah farmers and ranchers are in a better than average debt/asset position, but that net income per dollar of assets is below the national average. Consequently, it is important for Utah land purchasers (and likely those in other states) to base purchase decisions on the relationship between land prices and net returns to that land.

\section{Summary and Conclusions}

The purpose of this study was to determine whether the method of pricing rangeland has changed during the recent inflationdeflation land price cycle. The key questions were (1) Was rangeland, which has traditionally been priced according to carrying capacity, priced instead by the acre (hectare) during the inflation phase of the price cycle (1975-81)? and (2) During the deflation phase (1982-87) has the method of pricing returned to a price per AUM basis? Statistical analysis of 166 Utah land sales indicates that the answer to both of these questions is yes. An important implication of our study is that rangeland owners should try to maintain or improve range condition and carrying capacity in order to preserve real estate values during deflationary times.

\section{Literature Cited}

Andriot, J.J. 1983. Population abstract of the United States. Andriot Associates, McLean, Va.

Godfrey, E.B., and J.C. Andersen. 1988. A synopsis of the financial status of Utah agriculture. Utah Sci. 49:77-82.
Gertel, K. 1989. USDA Econ. Res. Serv., Washington, D.C. personal communication.

Gujarati, D.N. 1988. Basic econometrics. McGraw-Hill Book Co., N.Y. p. 444.

King, K.H. 1981. A determination of Utah ranch real estate values and an analysis of factors affecting these values. M.S. Thesis, Utah State Univ., Logan.

Rowan, R.C., and J.P. Workman. 1992. Factors affecting Utah ranch prices. J. Range Manage. 45:263-266.

Scott, J.T., Jr., 1983. Factors affecting land price decline. Amer. J. Agr. Econ. 65:796-800.

Suter, R.C. 1980. The appraisal of farm real estate. The Interstate Printers and Publishers, Inc., Danville, Ill.

Torell, L.A., and J.M. Fowler. 1986. A model for predicting trends of New Mexico grazing land values. New Mexico State Univ. Agr. Exp. Sta. Res. Bull. 723

U.S. Department of Agriculture. 1975-87, various issues. Agricultural prices. Nat. Agr. Stat. Serv., Washington, D.C.

U.S. Department of Agriculture. 1984. Farm real estate market developments. Econ. Res. Serv. Washington, D.C.

U.S. Department of Agriculture. 1985-88, various issues. Agricultural resources. Econ. Res. Serv., Washington, D.C.

U.S. Department of Commerce. 1975-87, various issues. Statistical abstract of the United States. National data book and guide to sources. Bureau of the Census, Washington, D.C.

Workman, J.P., and K.H. King. 1982. Utah cattle ranch prices. Utah Sci. 43:78-81. 